\title{
(2) OPEN ACCESS \\ Intrahepatic cholestasis of pregnancy resistant to both therapeutic plasma exchange and albumin dialysis
}

\author{
Massimiliano Lia 이, ${ }^{1}$ Thomas Berg, ${ }^{2}$ Laura Christina Weydandt, ${ }^{1}$ Holger Stepan ${ }^{1}$
}

'Department of Obstetrics, Leipzig University Hospital, Leipzig, Germany

'Department of Hepatology, Leipzig University Hospital, Leipzig, Germany

\section{Correspondence to}

Dr Massimiliano Lia; massimiliano.lia@medizin.unileipzig.de

Accepted 6 January 2022
Check for updates

(C) BMJ Publishing Group Limited 2022. Re-use permitted under CC BY-NC. No commercial re-use. See rights and permissions. Published by BMJ.

To cite: Lia M, Berg T, Weydandt LC, et al. BMJ Case Rep 2022:15:e246318. doi:10.1136/bcr-2021 246318

\section{SUMMARY}

Intrahepatic cholestasis in pregnancy (ICP) represents, depending on its severity, a serious risk for the fetus. Those cases with unusually high bile acid levels may be resistant to pharmaceutical treatment and can be treated with plasma exchange or albumin dialysis. However, the success rate of these therapeutic options and the factors influencing therapeutic response are unknown. Furthermore, if these options fail to improve ICP and serum bile acid levels are very high ( $>200$ $\mu \mathrm{m} / \mathrm{L}$ ), there are no clear recommendations when delivery should be planned. Here, we report a patient with severe ICP resistant to both therapeutic plasma exchange and albumin dialysis. Caesarean section was performed at 32 weeks of gestation followed by rapid remission of ICP.

\section{BACKGROUND}

Intrahepatic cholestasis of pregnancy (ICP) is characterised by the presence of pruritus and abnormal liver function tests (including elevated bile acids) in the absence of other pathologies. ${ }^{12}$ Even though pruritus represents the cardinal feature of ICP, jaundice seemed to be the more central symptom in the early literature. This condition was named 'idiopathic jaundice of pregnancy' by Eppinger, ${ }^{3}$ or 'recurrent jaundice of pregnancy' by Svaborg. ${ }^{4}$ However, according to more recent studies, jaundice is present in approximately $15 \%-20 \%$ of women with ICP. ${ }^{5}$ Hence, jaundice seems to indicate severe disease while pruritus may often be the first symptom preceding the diagnosis of ICP. ${ }^{1} \mathrm{High}$ levels of serum bile acids and bilirubin are associated with poor neonatal outcome, including stillbirth, asphyxial events and spontaneous preterm birth. ${ }^{78}$ Thus, severe ICP may not only cause symptoms in the woman, which are resistant to pharmaceutical treatment, but also represent a serious risk for the fetus. However, it is not clear how long a pregnancy complicated by severe ICP with very high bile acid levels ( $>200 \mu \mathrm{m} / \mathrm{L}$ ) can be prolonged and when delivery should be pursued.

Therapeutic plasma exchange is a relatively new approach in cases of severe ICP both to treat pruritus, decrease bile acids and consequently improve fetal outcome. In some case studies, therapeutic plasma exchange has shown good effects while other investigators reported no improvement by this therapy. ${ }^{9-12}$ To this day, the rate of successful plasma exchange or the factors influencing it are unknown.
The advanced organ support (ADVOS) is an extracorporal liver support procedure based on albumin dialysis, which aims to eliminate albuminbound toxins such as bile acids. ${ }^{13}$ However, there is no literature that reports this approach in pregnant women with ICP.

\section{CASE PRESENTATION}

We present a G3P0 with newly appeared jaundice at 20 weeks of gestation. Fever, vomiting, abdominal pain or influenza like symptoms were not present. Her urine was dark, her stools were light and she did not report about pruritus. She had a history of Crohn's disease for which she has been taking azathioprine and mesalazine for the previous 4 years. She did not take steroid and did not have surgery for that condition in the past. Other medical conditions (eg, preexisting liver dysfunction) were absent and the pregnancy was conceived without assisted reproductive technology. She underwent amniocentesis due to hydramnios, which showed a normal karyotype. Virological examination was negative for herpes simplex virus, Epstein-Barr virus, cytomegalovirus, varicella-zoster virus, SARSCoV-2 and hepatitis A, B, C and E. Ultrasound found no evidence of obstruction of the bilary ducts and the fetus showed normal growth and normal umbilical artery Doppler. Serum sFlt-1 and Placental Growth Factor (PlGF) were normal and proteinuria or hypertension was absent. Laboratory studies at 20 weeks of gestation returned as follows: alanine aminotransferase (ALAT) $49 \mathrm{U} / \mathrm{L}$ (reference value: $10-34 \mathrm{U} / \mathrm{L}$ ), bile acids $249 \mu \mathrm{m} / \mathrm{L}$ (reference

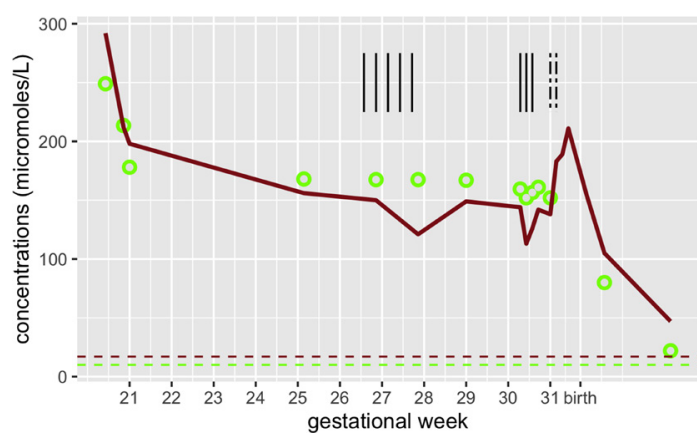

Figure 1 Biochemical parameters during pregnancy and postpartum. Total bilirubin (solid line) and bile acids (circles) show a pronounced elevation compared with the upper reference limit (horizontal dashed line) without significant response to plasma exchange (vertical solid lines) or albumin dialysis (vertical dashed line). 
Table 1 Clinical features and outcomes of reported ICP cases with very high bile acids $(>200 \mu \mathrm{m} / \mathrm{L})$

\begin{tabular}{|c|c|c|c|c|c|c|c|}
\hline Reference & $\begin{array}{l}\text { Peak contentration } \\
\text { of bile acids }(\mu \mathrm{m} / \mathrm{L})\end{array}$ & $\begin{array}{l}\text { Therapeutic } \\
\text { plasma exchange }\end{array}$ & $\begin{array}{l}\text { Gestational week } \\
\text { at delivery }\end{array}$ & Mode of delivery & CTG changes & Apgar scores* & $\begin{array}{l}\text { Days in the } \\
\text { NICU }\end{array}$ \\
\hline Keitel et $a l^{15}$ & 202 & No & 35 th & Spontaneous delivery & $\mathrm{N} / \mathrm{A}$ & $8^{1}-8^{5}-9^{10}$ & None \\
\hline Steele ${ }^{27}$ & 205 & No & $33 r d$ & $\begin{array}{l}\text { Emergency caesarean } \\
\text { section }\end{array}$ & Prolonged bradycardia & $0^{1}-5^{5}-9^{10}$ & 3 weeks \\
\hline Favre $e t a^{23}$ & 223 & No & 31 st & Caesarean section & None & \multicolumn{2}{|c|}{ Intrauterine fetal demise } \\
\hline Johnston et $a^{l^{26}}$ & 217 & No & 31 st & $\begin{array}{l}\text { Caesarean section } \\
\text { (PPROM, akute } \\
\text { Chorioamnionitis) }\end{array}$ & $\mathrm{N} / \mathrm{A}$ & $\mathrm{N} / \mathrm{A}$ & $\mathrm{N} / \mathrm{A}$ \\
\hline \multirow[t]{2}{*}{ Polewiczowska et al ${ }^{11}$} & 205 & No & $32 n d$ & $\begin{array}{l}\text { Emergency caesarean } \\
\text { section }\end{array}$ & Prolonged bradycardia & $5^{5}-9^{10}$ & 2 weeks \\
\hline & 230 & Yes & 31 st & $\begin{array}{l}\text { Planned caesarean } \\
\text { section }\end{array}$ & None & $4^{1}-7^{5}$ & None \\
\hline Hubschmann et a ${ }^{29}$ & 243 & No & $32 n d$ & $\begin{array}{l}\text { Planned caesarean } \\
\text { section }\end{array}$ & None & $8^{1}-2^{5}-9^{10}$ & None \\
\hline \multirow[t]{3}{*}{ Ovadia et a $I^{10}$} & 360 & Yes & 35th & $\begin{array}{l}\text { Planned caesarean } \\
\text { section }\end{array}$ & None & $7^{1}-8^{5}$ & $>24$ hour \\
\hline & 290 & Yes & $32 n d$ & $\begin{array}{l}\text { Emergency caesarean } \\
\text { section }\end{array}$ & N/A & $4^{1}-7^{5}$ & $>24$ hour \\
\hline & 440 & Yes & $32 n d$ & $\begin{array}{l}\text { Emergency caesarean } \\
\text { section }\end{array}$ & $\begin{array}{l}\text { Non-reassuring fetal } \\
\text { heart rate }\end{array}$ & $6^{1}-7^{5}$ & $>24$ hour \\
\hline Wongjarupong et $a l^{\beta 0}$ & 462 & No & 35th & Induction of labour & $\mathrm{N} / \mathrm{A}$ & $\mathrm{N} / \mathrm{A}$ & None \\
\hline
\end{tabular}

N/A indicates that the information is not available.

${ }^{*}$ Superscript number indicates minutes at which Apgar scores were calculated.

CTG, cardiotocography; ICP, intrahepatic cholestasis in pregnancy; NICU, neonatal intensive care unit; PPROM, preterm premature rupture of the membranes.

value: $0-10 \mu \mathrm{m} / \mathrm{L}$ ), total bilirubin $292 \mu \mathrm{m} / \mathrm{L}$ (reference value: 0-17 $\mu \mathrm{m} / \mathrm{L})$. Indirect bilirubin, gamma-glutamyl transferase and prothrombin time were normal. Albumin $(25 \mathrm{~g} / \mathrm{L})$ and total protein $(46 \mathrm{~g} / \mathrm{L})$ were decreased.

\section{TREATMENT}

Therapy with ursodeoxycholic acid was initiated $(1 \mathrm{~g} /$ day until delivery) without sufficient effect, as both serum bile acids and total bilirubin remained high. At 26 weeks of gestation, therapeutic plasma exchange was begun. A total of eight cycles of plasma exchange and two cycles of albumin dialysis (ADVOS) were performed without improvement of either bilirubin or bile acids (figure 1). Additionally, rising levels of transaminases (ALAT-peak: 148 U/L) and gamma glutamyltransferase (peak: $97 \mathrm{U} / \mathrm{L}$ ) were observed and, thus, the decision was made to deliver the baby by caesarean section at 32 weeks of gestation after antenatal corticosteroids. Both surgery and the neonatal course were uneventful.

\section{OUTCOME AND FOLLOW-UP}

The patient showed a rapid improvement of bilirubin and bile acid levels and was discharged 4 days after the operation. The genetic analysis from blood samples did not detect any gene variants associated with severe cholestatic hepatopathy. However, the patient was homozygous for a bile salt export pump variant (V444A), which is associated with low expression of the encoded export pump and, thus, may have contributed to the severity of this clinical course. ${ }^{1415}$

\section{DISCUSSION}

ICP may be resistant to medical treatment in a significant proportion of women. ${ }^{16}$ Especially cases with severe ICP may only respond to plasma exchange, which has been first reported by Warren and colleagues. ${ }^{12}$ Since then, there have been various attempts to use this therapy in cases resistant to pharmaceutical treatment with encouraging results. ${ }^{10} 11$ However, Covach and colleagues first reported a case of ICP resistant even to repeated plasma exchange. ${ }^{9}$ Similarly, our patient also showed a lack of improvement with plasma exchange and albumin dialysis, thus raising the question of how effective this therapy truly is. Interestingly, both the case of Covach et al and our case showed some sort of pre-existing liver disease. The patient of the former case report had active hepatitis $\mathrm{C}$, which has been associated with an increased severity of ICP. ${ }^{17}$ The woman in our case report had Crohn's disease, which may have negative effects on liver function. ${ }^{18}$ Hence, diseases afflicting the liver may limit the effect of plasma exchange in ICP. A very recent study also found that women treated with azathioprine who developed ICP often experienced a significant improvement if this medication was discontinued. ${ }^{19}$ Consequently, the azathioprine taken by our patient may have negatively influenced the effect of therapeutic plasma exchange and albumin dialysis. However, more research is required to determine the predictive factors for successful plasma exchange, as this treatment is both costly and invasive.

Interestingly, our patient did not suffer from pruritus, which is regarded as the most characteristic symptom and a prerequisite for the diagnosis of ICP. ${ }^{8}{ }^{20}$ However, the Royal College of Obstetricians and Gynaecologists (RCOG) guideline states that otherwise unexplained elevation of bile acids or other abnormal liver parameters may be sufficient even without pruritus for the diagnosis of ICP. ${ }^{2}$ It is, therefore, difficult to estimate the proportion of patients presenting with ICP without itch, as the definition of this condition is not universally agreed on and changed over the decades. When ICP was mainly defined by the presence of jaundice, several cases without pruritus have in fact been reported. Eliakim et al reported five cases of 'recurrent jaundice of pregnancy' of which one did not have any pruritus. ${ }^{21}$ Svanborg and Ohlsson found that pruritus was absent in 5 out of their 22 cases. $^{4}$ Additionally, the constellation of very high bile acids and bilirubin without pruritus may not be unusual, as these parameters do not correlate well with each other. ${ }^{22} 23$ Progesterone sulfates and autotaxin activity may play a more important 
role in the pathogenesis of pruritus in ICP. ${ }^{24} 25$ Notably, the total bilirubin levels measured in this case are unusually high for ICP since concentrations reported by other authors (table 1) were not higher than $106 \mu \mathrm{m} / \mathrm{L} .^{26}$

It is not clear when fetuses subjected to such severe ICP should be delivered. A meta-analysis by Ovadia and colleagues showed that the risk of stillbirth was best predicted by total bile acids and bilirubin. Especially bile acids higher than $100 \mu \mathrm{m} / \mathrm{L}$ were associated with increased risk of stillbirth. ${ }^{7}$ Interestingly, case reports describing ICP with very high bile acids levels (over $200 \mu \mathrm{m} / \mathrm{L}$ ) often describe non-reassuring fetal heart rate patterns around the 32nd week of gestation leading to emergency caesarean section. ${ }^{10} 1127$ Also, intrauterine fetal demise has been reported around this gestational week if bile acids were very high. ${ }^{23}$ These observations could be due to a vasoconstrictive effect of bile acids on placental veins, ${ }^{28}$ consequently causing fetal compromise. Hence, in pregnant women afflicted by ICP with very high bile acids and resistant to treatment, it seems prudent to plan delivery at 32 weeks of gestation, as emergency caesarean section and poor neonatal outcome (low Apgar, need of neonatal intensive care) have been reported by various authors (table 1 ).

However, further research is needed to determine when babies subjected to such high bile acids should be delivered and which factors influence the success of plasma exchange in severe ICP.

\section{Learning points}

- Intrahepatic cholestasis of pregnancy with very high bile acid levels and jaundice is rare.

- Therapeutic plasma exchange and/or albumin dialysis may not always be effective in patients with intrahepatic cholestasis of pregnancy and very high bile acid levels.

- There is a significant risk to the fetus with very high bile acid levels (over $200 \mu \mathrm{m} / \mathrm{L}$ ) and early delivery should be considered. Most cases reported in the literature have been delivered between 31 and 33 weeks of gestation.

Contributors Literature search and manuscript writing: ML and LCW. Manuscript revision: TB and HS. Graph creation: ML. Treatment of the patient: ML, TB, LCW and HS. Follow-up of the patient: TB.

Funding The authors have not declared a specific grant for this research from any funding agency in the public, commercial or not-for-profit sectors.

Competing interests None declared.

Patient consent for publication Consent obtained directly from patient(s).

Provenance and peer review Not commissioned; externally peer reviewed.

Open access This is an open access article distributed in accordance with the Creative Commons Attribution Non Commercial (CC BY-NC 4.0) license, which permits others to distribute, remix, adapt, build upon this work non-commercially, and license their derivative works on different terms, provided the original work is properly cited and the use is non-commercial. See: http://creativecommons.org/ licenses/by-nc/4.0/.

Case reports provide a valuable learning resource for the scientific community and can indicate areas of interest for future research. They should not be used in isolation to guide treatment choices or public health policy.

\section{ORCID iD}

Massimiliano Lia http://orcid.org/0000-0001-8285-3792

\section{REFERENCES}

1 Kenyon AP, Piercy CN, Girling J, et al. Obstetric cholestasis, outcome with active management: a series of 70 cases. BJOG 2002;109:282-8.
2 Kenyon AP, Girling JC, on behalf of the Royal College of Obstetricians and Gynaecologists. Obstetric cholestasis. Green-top guideline No. 43, 2011. Available: https://www.rcog.org.uk/globalassets/documents/guidelines/gtg_43.pdf

3 Eppinger H. Die Leberkrankheiten. Berlin: Springer Verlag, 1937.

4 SVANBORG A, OHLSSON S. Recurrent jaundice of pregnancy; a clinical study of twenty-two cases. Am J Med 1959:27:40-9.

5 Reyes $\mathrm{H}$. The spectrum of liver and gastrointestinal disease seen in cholestasis of pregnancy. Gastroenterol Clin North Am 1992:21:905-21.

6 Reyes H, Gonzalez MC, Ribalta J, et al. Prevalence of intrahepatic cholestasis of pregnancy in Chile. Ann Intern Med 1978;88:487-93.

7 Ovadia C, Seed PT, Sklavounos A, et al. Association of adverse perinatal outcomes of intrahepatic cholestasis of pregnancy with biochemical markers: results of aggregate and individual patient data meta-analyses. Lancet 2019:393:899-909.

8 Glantz A, Marschall H-U, Mattsson L-A. Intrahepatic cholestasis of pregnancy: relationships between bile acid levels and fetal complication rates. Hepatology 2004;40:467-74.

9 Covach AJ, Rose WN. Intrahepatic cholestasis of pregnancy refractory to multiple medical therapies and plasmapheresis. AJP Rep 2017;7:e223-5.

10 Ovadia C, Lövgren-Sandblom A, Edwards LA, et al. Therapeutic plasma exchange as a novel treatment for severe intrahepatic cholestasis of pregnancy: case series and mechanism of action. J Clin Apher 2018;33:638-44.

11 Polewiczowska B, Gautam N, Wessels J, et al. Plasmapheresis in management of severe cholestasis of pregnancy. J Case Rep Images Gynecol Obstet 2016;2:14-19.

12 Warren JE, Blaylock RC, Silver RM. Plasmapheresis for the treatment of intrahepatic cholestasis of pregnancy refractory to medical treatment. Am J Obstet Gynecol 2005:192:2088-9.

13 Huber W, Henschel B, Schmid R, et al. First clinical experience in 14 patients treated with ADVOS: a study on feasibility, safety and efficacy of a new type of albumin dialysis. BMC Gastroenterol 2017;17:32

14 Meier Y, Pauli-Magnus C, Zanger UM, et al. Interindividual variability of canalicular ATP-binding-cassette (ABC)-transporter expression in human liver. Hepatology 2006;44:62-74.

15 Keitel V, Vogt C, Häussinger D, et al. Combined mutations of canalicular transporter proteins cause severe intrahepatic cholestasis of pregnancy. Gastroenterology 2006:131:624-9.

16 Roncaglia N, Locatelli A, Arreghini A, et al. A randomised controlled trial of ursodeoxycholic acid and S-adenosyl-L-methionine in the treatment of gestational cholestasis. BJOG 2004;111:17-21.

17 Locatelli A, Roncaglia N, Arreghini A, et al. Hepatitis C virus infection is associated with a higher incidence of cholestasis of pregnancy. Br J Obstet Gynaecol 1999;106:498-500.

18 Rasmussen HH, Fallingborg JF, Mortensen PB, et al. Hepatobiliary dysfunction and primary sclerosing cholangitis in patients with Crohn's disease. Scand I Gastroenterol 1997:32:604-10.

19 Céruti H, Kayem G, Guilbaud L, et al. Intrahepatic cholestasis of pregnancy associated with azathioprine: a case series. J Gynecol Obstet Hum Reprod 2021;50:102083.

20 Bunchorntavakul C, Reddy KR. Pruritus in chronic cholestatic liver disease. Clin Liver Dis 2012;16:331-46.

21 Eliakim M, Sadovsky E, Stein O, et al. Recurrent cholestatic jaundice of pregnancy. Report of five cases and electron microscopic observations. Arch Intern Med 1966;117:696-705.

22 Heikkinen J, Mäentausta O, Ylöstalo P, et al. Serum bile acid levels in intrahepatic cholestasis of pregnancy during treatment with phenobarbital or cholestyramine. Eur $J$ Obstet Gynecol Reprod Biol 1982;14:153-62.

23 Favre N, Abergel A, Blanc P, et al. Unusual presentation of severe intrahepatic cholestasis of pregnancy leading to fetal death. Obstet Gynecol 2009;114:491-3.

24 Abu-Hayyeh S, Ovadia C, Lieu T, et al. Prognostic and mechanistic potential of progesterone sulfates in intrahepatic cholestasis of pregnancy and pruritus gravidarum. Hepatology 2016;63:1287-98.

25 Heerkens M, Dedden S, Scheepers H, et al. Effect of plasmapheresis on cholestatic pruritus and autotaxin activity during pregnancy. Hepatology 2019:69:2707-10.

26 Johnston RC, Stephenson ML, Nageotte MP. Novel heterozygous ABCB4 gene mutation causing recurrent first-trimester intrahepatic cholestasis of pregnancy. J Perinatol 2014:34:711-2.

27 Steele G. Reflection on a pregnancy complicated by obstetric cholestasis. Pract Midwife 2012:15:30-2.

28 Sepúlveda WH, González C, Cruz MA, et al. Vasoconstrictive effect of bile acids on isolated human placental chorionic veins. Eur J Obstet Gynecol Reprod Biol 1991;42:211-5.

29 Hubschmann AG, Orzechowski KM, Berghella V. Severe first trimester recurrent intrahepatic cholestasis of pregnancy: a case report and literature review. AJP Rep 2016:6:e38-41.

30 Wongjarupong N, Bharmal S, Lim N. Never too soon: an unusual case of intrahepatic cholestasis of pregnancy at five weeks gestation. Cureus 2020;12:e10540. 
Copyright 2022 BMJ Publishing Group. All rights reserved. For permission to reuse any of this content visit https://www.bmj.com/company/products-services/rights-and-licensing/permissions/

BMJ Case Report Fellows may re-use this article for personal use and teaching without any further permission.

Become a Fellow of BMJ Case Reports today and you can:

- Submit as many cases as you like

- Enjoy fast sympathetic peer review and rapid publication of accepted articles

Access all the published articles

Re-use any of the published material for personal use and teaching without further permission

Customer Service

If you have any further queries about your subscription, please contact our customer services team on +44 (0) 2071111105 or via email at support@bmj.com.

Visit casereports.bmj.com for more articles like this and to become a Fellow 